\author{
Maciej Nawrocki \\ Uniwersytet Jagielloński, Kraków \\ m.nawrocki@uj.edu.pl
}

\title{
Mit Smoleńska w piśmiennictwie polskim XVII wieku - przypadek Jana Kunowskiego
}

\begin{abstract}
The Myth of Smolensk in the Polish Literature of $17^{\text {th }}$ Century - The Case of Jan Kunowski

The study analyses several selected poetic works by Jan Kunowski (ca. 1592-1654) related to the city of Smolensk and the war between the Polish-Lithuanian Commonwealth and Muscovy (1632-1634), also referred to as the Smolensk War. Using this case study, the author presents the Smolensk's place in the political awareness of the contemporary Polish nobility and discusses some themes exploited by modern propaganda devoted to this event.

Having a general sketch of the "myth of Smolensk" (that is the Polish narrative on this city before the war) as the starting point allows a deepened interpretation of Kunowski's poems concerning the conflict alone, in which the representation of the city and the topics used by the poet change substantially. Thanks to individual interpretations the author exposes characteristic crucial points of the narrative and demonstrates how they work on two levels: of the propaganda and the myth.
\end{abstract}

Key words: Smolensk, Smolensk War, Jan Kunowski, propaganda, mythization 


\section{Wstęp}

Wojna smoleńska (1632-1634), czyli jeden z kilku wczesnonowożytnych konfliktów zbrojnych między Rzecząpospolitą Obojga Narodów a Carstwem Rosyjskim, należy do najważniejszych wydarzeń politycznych tamtego okresu. Smoleńsk, jedno z najstarszych miast całej Rusi, leżące na pograniczu moskiewsko-litewskim, kilkukrotnie w późnym średniowieczu i wczesnej nowożytności zmieniało swoją przynależność polityczną. Kontrola nad ziemią smoleńską była dla Rosji, Litwy, a później Rzeczypospolitej Obojga Narodów o tyle ważna, że to właśnie tamtędy wiódł główny (zasadniczo nawet jedyny) szlak handlowy i militarny, łączący Warszawę, Wilno i Moskwę. Sam zaś Smoleńsk nazywano zarówno „kluczem Moskwy”, jak i „kluczem Litwy”, ponieważ jego dogodne ze względów strategicznych położenie na wzgórzach, między bagnami i jeziorami północy a lasami i rzekami południa, umożliwiało stworzenie bazy operacyjnej dla hipotetycznych manewrów wojskowych na obu terytoriach ${ }^{1}$.

Pograniczne położenie Smoleńska spowodowało, że miasto na przestrzeni wieków znajdowało się w różnych strefach wpływu i podlegało kolonizacji. Mimo stosunkowo długiej historii księstwa smoleńskiego oraz, jak się wydaje, dość jednolitej struktury etnicznej i religijnej miasta, prawa do niego, które rościły sobie w XVII wieku Rzeczpospolita i Moskwa, były dyplomatycznie równoważne, zaś obydwie strony tego konfliktu uważały ziemię smoleńską za niezbywalną część swojego państwa. Nieuchronną konsekwencją takiej sytuacji były wielokrotne starcia zbrojne, a za panowania polskich Wazów Smoleńsk trzy razy stanowił arenę dla wojen polsko-rosyjskich $^{2}$. Zwycięstwo Władysława IV Wazy nad moskiewskimi wojska-

1 Zob. D. Kupisz, Smoleńsk 1632-1634, Warszawa 2001, s. 9-14.

2 Pierwsza $\mathrm{z}$ nich, toczona przez Zygmunta III w latach 1609-1618 agresywna „wojna moskiewska”, zakończyła się rozejmem w Dywilinie, na mocy którego przyznano Rzeczypospolitej opanowaną w 1611 roku ziemię smoleńską; trzecia z kolei to rosyjska inwazja rozpoczęta w 1654 roku, za panowania Jana II Kazimierza, a za- 
mi dowodzonymi przez Michała Szeina podczas drugiej z nich było dla Korony szczególnie cenne ze względów nie tylko terytorialnych i ekonomicznych, ale też - a być może przede wszystkim - propagandowych, o czym świadczy zarówno wielość, jak i różnorodność siedemnastowiecznych tekstów kultury poświęconych tej kampanii ${ }^{3}$. Niniejszy artykuł jest analizą kilku wybranych dzieł Jana Kunowskiego poświęconych Smoleńskowi. Na ich podstawie zamierzam pokazać rozmaite strategie propagandowe charakterystyczne dla epoki wazowskiej oraz dokładnie określić funkcję wojny smoleńskiej w oficjalnej, państwowej narracji.

Doprecyzowania w tym miejscu wymaga sam termin „propaganda”, współczesnym ludziom niewątpliwie bardziej kojarzący się $\mathrm{z}$ historią wieku XX, a jednak stosunkowo często znajdujący zastosowanie w pracach dotyczących kultury i sztuki wczesnonowożytnej. Ponad trzydzieści lat temu Juliusz Chrościcki w książce zatytułowanej Sztuka $i$ polityka. Funkcje propagandowe sztuki $w$ epoce Wazów 1587-1668 wymieniał wielu rodzimych badaczy sztuki dawnej używających tej kategorii do opisu renesansowych i barokowych dzieł zajmujących szczególne miejsce w publicznej sferze Rzeczypospolitej ${ }^{4}$. Ważnym opracowaniem tej problematyki jest także rozprawa Urszuli Augustyniak Informacja $i$ propaganda $w$ Polsce $z a$ Zygmunta III, wydane w 1981 roku. Badaczka we wstępie tłumaczy

kończona przez pokój andruszowski w 1667 roku; w jego wyniku Rzeczpospolita Obojga Narodów bezpowrotnie utraciła kontrolę nad województwem smoleńskim.

Najważniejsze spośród nich to epickie dzieła Samuela Twardowskiego: Szczęśliwa moskiewska ekspedycyja Najjaśniejszego Władysława IV, króla polskiego i szwedzkiego (1634) oraz Władysław IV, król polski i szwedzki (1649); epizod smoleński był także przedmiotem zainteresowania m.in. biografa królewskiego Eberharda Wassenberga, autora Gestorum gloriosissimi ac invictissimi Vladislai IV (1641). Inne teksty kultury poświęcone temu wydarzeniu to dzieła takich artystów jak Jan Chrystian Bierpfaff (sarkofag Władysława IV na Wawelu, 1649), Sebastian Dadler i Jan Höhn (medale okolicznościowe, 1634-1637), Wilhelm Hondius oraz Salomon Savery (grafiki, 1635-1636).

4 J. Chrościcki, Sztuka i polityka. Funkcje propagandowe sztuki w epoce Wazów 1587-1668, Warszawa 1983, s. 18-19. 
tytułowe rozróżnienie na informację i propagandę w następujący sposób:

Formułując wzajemny stosunek terminów informacja i propaganda w przyjętych w niniejszej pracy znaczeniach, stwierdzić można, iż term in informacja występuje w dwojakim znaczeniu:

- jako zespół komunikatów nadawanych i odbieranych przez ludzi,

- jako działanie zmierzające do przekazywania komponentów intelektualno-poznawczych tych komunikatów w opozycji do działania propagandowego, odwołującego się przede wszystkim do ich komponentów emocjonalnych ${ }^{5}$.

Wydaje mi się jednak, że - co szczególnie istotne dla mojej interpretacji - trudno w sposób klarowny zarysować granice pomiędzy informacyjną a emotywną funkcją wielu tekstów kultury, zwłaszcza jeśli mamy do czynienia $\mathrm{z}$ dziełami opisującymi historię (mniej lub bardziej) współczesną danemu autorowi. Zakwestionowanie powyższej opozycji oznacza w tym przypadku nie tylko podejrzliwość względem pojęcia obiektywnej informacji, ale także możliwość spojrzenia na zjawisko propagandy z perspektywy mniej związanej z wartościowaniem ${ }^{6}$.

W moim rozumieniu propagandowy tekst kultury spełnia następujące warunki: po pierwsze, jest skierowany do licznej grupy odbiorców lub szczególnie prominentnych jednostek (np. władców, szlachty); po drugie, odnosi się do określonej i aktualnej sytuacji politycznej; po trzecie, używa takich środków wyrazu, które służą wartościowaniu i perswazji. Celem propagandy jest osiągnięcie konkretnych, doraźnych lub długofalowych celów społeczno-politycznych oraz kształtowanie postaw i poglądów osób i grup, które mają wpływ na politykę. Niniejsza definicja pozwala zarówno na stosunkowo

5 U. Augustyniak, Informacja i propaganda w Polsce za Zygmunta III, Warszawa 1981, s. 7 (podkr. U.A.).

${ }^{6}$ O tego rodzaju rozważaniach dotyczących obiektywizmu w humanistyce zob. np. S. Fish, Retoryka, przeł. A. Szahaj, w: idem, Interpretacja, retoryka, polityka, przeł. K. Arbiszewski i in., red. A. Szahaj, Kraków 2002, s. 421-462. 
precyzyjne wyznaczenie pola badawczego, jak i na interdyscyplinarną swobodę.

Ponadto proponuję spojrzeć na teksty propagandowe nie tylko, jak chce Augustyniak, jako na jednoznacznie szkodliwe społecznie ${ }^{7}$ narzędzia chłodnej manipulacji, zmierzającej do bezwzględnego podporządkowania jednostki konkretnemu organizmowi politycznemu, ale także jako na jeden $\mathrm{z}$ elementów naturalnego procesu konstruowania się zbiorowych tożsamości. Bliżej jest więc mojemu rozumieniu propagandy do ujęcia Chrościckiego, który szczególny nacisk kładzie na „świadomy dydaktyzm i poczucie społecznej użyteczności słowa [które] miały na celu rozbudowanie oddziaływania na sferę emocjonalną odbiorcy"".

Moim zamiarem jest nie tylko wyodrębnienie poszczególnych elementów mityczno-historycznej narracji o Smoleńsku w poezji Kunowskiego, ale także próba określenia czynników decydujących o strukturze tej opowieści. Chcę wyjaśnić, w jakim celu dobierano konkretne formy, gatunki, toposy i symbole oraz jak budowano ich wspólne znaczenie - wycinek tego rodzaju propagandowej twórczości, jakim są wiersze Jana Kunowskiego, stanowi doskonały punkt wyjściowy dla tej refleksji.

\section{Ziemia smoleńska - ziemia obiecana}

Okoliczności polityczne przekładające się na niepewność utrzymania władzy nad zdobytym terytorium zasadniczo już od momentu przyłączenia Smoleńska do państwa Wazów sprzyjały powstawaniu wielu propagandowych tekstów kultury dotyczących miasta. Zaistniała bowiem potrzeba włączenia nowo pozyskanej ziemi w szerszą narrację państwową, uwzględniającą prawa nie tylko Wielkiego Księstwa

\footnotetext{
U. Augustyniak, Informacja i propaganda..., s. 8.

8 J. Chrościcki, Sztuka i polityka..., s. 14.
} 
Litewskiego, ale także Korony. Duży udział w procesie zakorzeniania Smoleńska w Rzeczypospolitej Obojga Narodów miała napływająca tam katolicka i protestancka polsko-litewska administracja.

Przedstawicielem tej grupy był Jan Kunowski (ok. 1592-1654), średniozamożny szlachcic, łączony przez historyków z Kunowskimi herbu Łodzia, zamieszkałymi w powiecie mozyrskim, należącym administracyjnie do województwa mińskiego9. Protegowany wojewody smoleńskiego, sławnego dowódcy i dyplomaty, Aleksandra Gosiewskiego, zrobił szybką (choć ze względu na swoje ewangelickie wyznanie napotykającą czasem spore przeszkody) karierę, najpierw wojskową, później zaś dworską, jako królewski sekretarz Władysława IV. Kunowski brał udział w kampaniach Gosiewskiego od około 1615 roku, walcząc między innymi z wojskami moskiewskimi, blokującymi zdobyty przez armię Rzeczypospolitej Smoleńsk podczas wojny toczonej w latach 1609-1618. Jako posiadacz dóbr ziemskich w okolicy został także wezwany, aby bronić smoleńskiej twierdzy w 1632 roku. Co najbardziej interesujące w kontekście tego wywodu, Kunowski był także poetą - pisał na przestrzeni kilku dekad, a jego twórczość dotyczy między innymi historii Smoleńska.

Smoleńska zacność $R<o k u>P<$ ańskiego $>1628^{10}$ to napisany jeszcze przed oblężeniem krótki opisowo-pochwalny poemat w strofach safickich, którego tematem jest Smoleńsk i jego dzieje. Według Dariusza Chemperka jest to także pierwszy napisany po polsku en-

9 Zob. np. K. Łopatecki, Wstęp, w: J. Kunowski, Ekspedycyja inflantska 1621 roku, oprac. K. Łopatecki, W. Walczak, Białystok 2007, s. 28-43. Kunowscy tego samego herbu mieszkali też w województwie płockim, zaś Kunowscy herbu Nałęcz posiadali dobra w okolicach Nakła; pochodzenie Jana Kunowskiego z którejkolwiek $\mathrm{z}$ tych rodzin raczej nie jest prawdopodobne.

${ }_{10}$ J. Kunowski, Smoleńska zacność $R<o k u>P<a n$ skiego $>1628$, w: Sprawa smoleńska. Z literatury okolicznościowej pierwszej połowy XVII wieku. Ze zbiorów Archiwum Narodowego Szwecji Skoklostersamlingen, wyd. M.M. Kacprzak, red. A. Nowicka-Jeżowa, Warszawa 2006, s. 25-32. 
komion poświęcony miastu Rzeczypospolitej ${ }^{11}$, choć z sądem tym można polemizować ${ }^{12}$. Na podstawie lektury tego utworu można wyodrębnić kilka popularnych wówczas strategii kształtowania mitycznej przeszłości grodu i Rzeczypospolitej Obojga Narodów.

Pierwsze strofy wymieniają Smoleńsk niemal w jednym rzędzie z greckimi miastami-ikonami - Atenami, Spartą i Konstantynopolem (zwanym tu Carygrodem) - przywołanymi po to, aby na ich przykładzie ukazać przemijalność wielowiekowych królestw. Pod jarzmem tureckim grecka ludność została zmuszona, by toczyć bratobójczą walkę z krajami chrześcijańskimi:

Sławne Ateny i miasto spartańskie -

Aza nie znaczne są przykłady Pańskie,

Iż nic trwałego nie ma świat u siebie?

Dom wieczny w niebie.

Jednakże sławą miasta żyją mnogie,

Odniósszy w murach zbyt zniszczenie srogie.

Persom Grecyja i dziś strach przynosi,

Acz turecki nosi

Tytuł na sobie. Ale greccy ludzie

Musieli podlec pogańskiej obłudzie,

Janiczarami z ćwiczenia nazwani,

Męstwem odziani.

Przez nich zwycięstwo Turek dziś odnosi,

A i krześcijan kosą swojąż kosi.

Carygród w sławę przyodział potężnie,

Zhołdował mężnie.

11 D. Chemperek, Obraz Smoleńska i jego mieszkańców w literaturze polskiej początku XVII wieku, „Terminus” 11 (2009), z. 1-2, s. 299-301.

12 Jako kontrprzykłady można chociażby wskazać kilka pisanych polszczyzną i wierszowanych pochwał siedemnastowiecznego Krakowa, autorstwa Sebastiana Petrycego z Pilzna czy Jana Jurkowskiego, zob. E. Buszewiczowa, Cracovia in litteris: obraz Krakowa w piśmiennictwie doby odrodzenia, Kraków 1998, szczególnie s. $189-190$. 
W ludziach, toć nie dziw, że prędka odmiana -

Coraz nowego śmierć podaje pana.

Ale królewstwa czemu prędko giną

Pod sprawą iną? ${ }^{13}$

Taki początek poematu spełnia dwie funkcje propagandowe: po pierwsze, przez analogię porównuje się tu Smoleńsk, znajdujący się już w granicach Rzeczypospolitej, do powszechnie znanych i niezwykle ważnych miast, kolebek kultury europejskiej; po drugie, kojarzy się Moskwę z Turcją - krajem islamskim, a zatem (w oczach dużej części chrześcijańskiej Europy) właściwie bezbożnym.

Niemniej według Kunowskiego czasy upadku i niewoli dla Smoleńska się skończyły, ponieważ w chwili pisania tego utworu prawowitą pieczę nad grodem sprawuje - z Bożego nadania - Rzeczpospolita Obojga Narodów, o którym to państwie pisze:

Dar to jest Boży, a niemniejszy prawie,

Gdy ono kwitnie, w dobrej żyjąc sprawie,

Czego i polskie lat tysiąc uznawa,

Sam Bóg to dawa.

Te dwa narody nieprzyjazne sobie -

Litwę z Polaki - spodobało Tobie,

O, Boże wieczny, tak z jednego zbracić,

Nie chcąc ich tracić ${ }^{14}$.

Po wyraźnym wskazaniu na boską proweniencję zjednoczenia Litwy i Korony następuje długi opis historii połączonych królestw (od zwycięstwa grunwaldzkiego w 1410 roku, kiedy to obowiązywała unia personalna zawarta w Krewie w 1385 roku) ze Smoleńskiem w tle. Ze wszystkich wojsk polskich odnoszących zwycięstwa ku chwale Boga jako najdzielniejszą przedstawia się właśnie załogę smoleńską; poeta pozwolił sobie nawet skrytykować „polską ozięb-

13 J. Kunowski, Smoleńska zacność..., s. 25.

14 Ibidem, s. 26. 
łość" i wynikające z niej nadmierne zaufanie do możliwości obronnych tego miasta w wojnie z 1514 roku.

Wspomniana wojna, która kosztowała Litwę utratę Smoleńska na blisko sto lat, posłużyła Kunowskiemu za ideologiczną podstawę dla budowy wizerunku Moskwy jako bezprawnego okupanta tych ziem. Poeta wyraźnie podkreśla, że Smoleńsk znalazł się pod rosyjską kontrolą za sprawą ciężkiego grzechu, czyli „przeklętej zdrady” księcia Glińskiego ${ }^{15}$, oraz zaniedbania i opieszałości ze strony polskiej (ale już nie litewskiej). Mimo uwzględnienia w Smoleńskiej zacności... tego, że miasto leży na terytorium spornym (wszak „któż zliczy kłotnie?"16), poeta zaznacza, że uświęcone Boskim mandatem prawo do niego ma najwyraźniej wyłącznie Rzeczpospolita Obojga Narodów. Kunowski sugeruje nawet jakoby sami Moskale nie uważali Smoleńska za prawowitą część swoich ziem - pisze bowiem, że „Widział Moskwicin: trudno cudze bronić, / Jednak przemyszlał, jako by ochronić"17.

Jednocześnie żadnej wątpliwości nie ulega tu zasadność wazowskich roszczeń względem Smoleńska. Zygmunt III jest w poemacie przedstawiony jako władca troskliwy i rozsądny, który dokłada wszelkich starań, aby ulżyć obleganemu grodowi - udaje mu się to, rzecz jasna, Deo iuvante:

To snadź król Zygmunt upatrując Trzeci

Z wojskiem pod Smoleńsk tak gorąco leci,

Rzewniej dobywać lat dwie usiłował,

Bóg forytował.

15 Ibidem. Ten i inny epizod związany ze zleceniem zabójstwa wojewody trockiego Jana Zabrzezińskiego włączyły na stulecia postać Michała Glińskiego jako personifikację buty i zdrady do polskiego dyskursu historycznego i narodowego; por. np. J.U. Niemcewicz, Duma o kniaziu Michale Glińskim, w: Śpiewy historyczne, oprac. M. Hanczakowski, Kraków 2002, s. 61-65.

16 J. Kunowski, Smoleńska zacność..., s. 27.

17 Ibidem (podkr. moje - M.N.). 
Przypatrz się zatem jego dbałej pieczy

Koło smoleńskiej długi czas odsieczy:

Aza nie pilno o swej pracy radził,

\section{Ani toż sadził}

Skarbu własnego, na koniec ugodą

Ochronić pragnął za naszą niezgodą?

I tym sposobem nie mogąc ochronić,

Inaczej bronić

Szuka sposobu. Radę tę najduje:

Wodza drugiego na to upatruje,

Aby dał odsiecz Smoleńskowi j e go -

Znaj pana swego.

Na tym nie zawiódł baczenia swojego,

Uwolnił Smoleńsk, kochania twojego.

Moskwicin rzuca ostrogi potężne

Przez ręce mężne ${ }^{18}$.

Poeta zwraca się tu bezpośrednio do domniemanego czytelnika, czyli mieszkańca Rzeczypospolitej Obojga Narodów, który ze względu na swoją przynależność etniczno-polityczną z pewnością „kocha” Smoleńsk i postrzega go jako nieodłączną część tego państwa.

W granicach Rzeczypospolitej odbity przez Zygmunta III Smoleńsk miał - według Kunowskiego - być po trzykroć szczęśliwy: dzięki miłości królewskiej, opiece dzielnego wojewody Aleksandra Gosiewskiego oraz napływowi mężnej szlachty; także na trzy sposoby gród wzbudzał respekt u nieprzyjaciół i trzykrotnie uszczęśliwiał wszystkich swoich dobrodziejów: króla, wojewodę i rycerstwo. Zastosowana przez poetę na wielu poziomach tekstu trójkowa konstrukcja dodatkowo wzmacnia powtarzający się przez większą część utworu przekaz, że mieszkańcy Rzeczypospolitej Obojga Narodów to ujęty w Boskim planie lud wybrany, nad którym nieustannie czuwa Opatrzność.

18 Ibidem, s. 28-29 (podkr. moje - M.N.). 
O ile pierwsza część omawianego tekstu wykorzystuje Smoleńsk jedynie jako tło, na którym rysuje się głównie kontrast między wspaniałą i chrześcijańską Rzecząpospolitą a zacofaną i niemal pogańską Moskwą, o tyle kolejne fragmenty mówią już o tytułowej zacności samego Smoleńska. Kunowski posługuje się klasycznym i bardzo charakterystycznym dla wczesnej nowożytności modelem opisu miasta ${ }^{19}$; rozpoczyna od omówienia szczegółów topograficznych (tu specjalną uwagę poświęca rzekom, czyniącym ze Smoleńska ruchliwy węzeł handlowy), aby potem przejść do opisu kolejno: fortyfikacji, kościołów, budynków użyteczności publicznej i domów mieszkalnych. Poetykę tego opisu najlepiej ilustruje poniższy, dość obszerny fragment:

Dziedziniec zacny Zamku potężnego

Zatrzymać zdoła nie wiem jak mężnego

Nieprzyjaciela, ludem opatrzony.

Słusznie sławiony

Śród murów kościół na górze biskupi

W ślicznym pojrzeniu - przyzna to i głupi -

Zamkowi sprawi niemniejszą ozdobę

Za krótką dobę.

Zatym, acz z drzewa, insze już kościoły -

A bernardyński, jako to wesoły,

A jezuicki poczytam ogromny,

Do tego skromny

Dominikański kościół i szpitalny -

Są położony na oryjentalny

Promień słoneczny. A ratusz do tego

Celuje swego,

19 Zob. np. M. Limbereger, A Merchant Describing the City. Lodovico Guicciardinis "Descrittione di tutti I Paesi Bassi" as a Source for the Urban History of the Low Countries, https://biblio.ugent.be/publication/936765/file/950595.pdf [dostęp: 9 I 2017]. 
Dom wojewodzi pokładając w głowach.

Po tym szlacheckie, nie sadząc na słowach,

Ozdobę miastu niepodł<ą $>$ przynoszą.

Zatym się wznoszą

Miejskie chałupy, a rynkowe domy

Zdobią ulicę do Królewskiej Bromy

I ta nie mniejszej godna jest pochwały,

Ma ubiór cały.

Już insze zamki sław kto, jako chęcy,

Ja Smoleńsk będę nade wszytkie więcéj! ${ }^{20}$

Co znamienne, większość obiektów chwalonych przez poetę i znajdujących się w granicach miasta jest jednocześnie symbolami polskiej i katolickiej obecności w Smoleńsku; kościoły (w tym biskupi), dom wojewody, Brama Królewska - to wszystko związane jest z wdrożeniem nowej administracji oraz próbą włączenia miasta w krąg dominacji kulturowej katolicyzmu. Ciekawi także, że Kunowski, sam będąc przecież ewangelikiem, wychwala nawet budowę świątyni jezuitów - wpływ na to miały prawdopodobnie bardzo silne związki tego zakonu z państwem Wazów. Laudację kończy klamrowe w stosunku do reszty utworu przywołanie wyspy Rodos i miasta Mityleny (największej osady Lesbos), gdzie powiedziane jest już wprost, że żadne $\mathrm{z}$ tych miejsc w swojej obronności i bogactwie naturalnym „nie ma [ze Smoleńskiem] ceny”21.

Tego rodzaju opis zawarty w wierszu świadczy o specyficznym dla wczesnej nowożytności myśleniu emblematycznym, czyli takim, które niemal automatycznie kojarzy tekst $z$ obrazem. Nie jest to jednakże obraz pozbawiony znaczeń naddanych - słowna mapa, którą sporządził Kunowski, jest mapą „polskiego” Smoleńska, w którego pejzażu dominują nie cerkwie, a kościoły, gdzie jedyne godne podziwu fortyfikacje to te zbudowane już za panowania Zygmunta III

20 J. Kunowski, Smoleńska zacność..., s. 31.
21 Ibidem. 
i gdzie mające z górą setki lat budynki noszą - jakby od wieków polskie imiona.

Portret Smoleńska nakreślony przez Kunowskiego jest bardzo silnie stopizowany; pokazane wyżej konkretne (nierzadko zresztą dość kunsztowne) zabiegi stylistyczne czynią całą Rzeczpospolitą Obojga Narodów miejscem mitycznym. Wspomniane strategie mają na celu włączenie wschodnich ziem Wielkiego Księstwa Litewskiego do katolicko- i miejscami polskocentrycznej metanarracji kształtującej polityczną ideologię państwa Wazów. Aktualizacja państwowego i narodowego mitu odbywa się tu dwufazowo: $\mathrm{z}$ jednej strony omawiany tekst zawiera powtórzenie najważniejszych punktów konstytutywnych dla polskiej (i po części także litewskiej) wczesnonowożytnej myśli państwowej, z drugiej zaś dodaje do "tysiącletniej” historii nowy element - Smoleńsk.

Żeby jednak naddnieprzański gród mógł odpowiednio funkcjonować w tej opowieści, sam musiał także nabrać cech właściwych dla przestrzeni mitycznej - jako przykład mogą tu posłużyć chociażby dwie ostatnie strofy utworu, które (zwłaszcza w kontekście panegirycznego charakteru tekstu) nadają Smoleńskowi cechy arkadyjskie i czynią z niego locus amoenus:

Tym Smoleńsk zacny stąd chwalebnie słynie,

Iż podeń rzeka najsławniejsza płynie,

Ówdzie obfite miewa urodzaje:

Miód, mleko, jaje,

Zbóż rozmaitych wzmiankować nie trzeba,

Aż nader piwa i wszelkiego chleba,

Mnóstwo ryb, zwierzu, rozmaite ptastwa

Nad gospodarstwa. ${ }^{22}$

Mimo że powyższy fragment dobrze wpisuje się w sięgające swoimi korzeniami antyku konwencje pochwały miast i ich warunków

22 J. Kunowski, Smoleńska zacnośćc.., s. 32. 
naturalnych ${ }^{23}$, to trudno jednak zignorować pojawiające się tu - także między wierszami - klasyczne wyznaczniki Arkadii, czyli „uroki krajobrazu” takie jak np. płynąca rzeka, urodzaj roślinności i rozmaite gatunki dzikiego ptactwa. Tradycja opisu locus amoenus (zwłaszcza ta późniejsza, wzbogacona o motywy średniowieczne) operuje częstokroć opozycjami i paradoksami, aby pokazać, że w miejscu doskonałym łączą się ze sobą pozornie przeciwstawne aspekty życia ziemskiego $^{24}$. Charakterystyczne jest, że w tym krótkim i pod wieloma względami nieprzystającym do reszty utworu fragmencie Smoleńsk zmienia się z tętniącej życiem metropolii, przez którą przechodzą główne szlaki handlowe tej części Europy, w miejsce sielskie (a więc nawet nie-miejskie), ciche, w nierozerwalny sposób związane z bujną, ale przede wszystkim łaskawą i przyjazną człowiekowi przyrodą. Poetycka wizja miasta w Smoleńskiej zacności... łączy w sobie więc pierwiastki tak kultury, jak i natury, co z jednej strony czyni tę przestrzeń niemal doskonałą, a z drugiej pozwala na wykorzystanie jej we wszelkiego rodzaju opowieściach, a zwłaszcza tych noszących znamiona mitu - może być tłem zarówno eposu, jak i bukoliki.

\section{Smoleńsk w ogniu}

Jako że obecnie dysponujemy jedynie rękopisami, trudno do końca określić zasięg, jaki miała poezja Jana Kunowskiego. Tym niemniej można z dużą dozą pewności scharakteryzować je jako propagandowe. Karol Łopatecki sugeruje, że Kunowski zwrócił na siebie uwagę i doszedł do - dość przecież znacznej - prominencji między innymi

23 Por. B.B. Awianowicz, „Urbes laudandi ratio”. Antyczna teoria pochwały miast i jej recepcja $w$ De inventione et amplificatione oratoria Gerarda Buccoldianusa oraz $w$ Essercitii di Aftonio Sofista Orazia Toscanelli, „Terminus” 11 (2009), z. 1-2, s. 17.

24 Por. E.R. Curtius, Literatura europejska i łacińskie średniowiecze, przeł. i oprac. A. Borowski, Kraków 2005, s. 191-207. 
dzięki panegirycznym utworom dedykowanym patronowi, Aleksandrowi Gosiewskiemu ${ }^{25}$. Jego twórczość musiała zatem być rozpowszechniana przynajmniej na lokalną skalę, prawdopodobnie na obszarze województwa smoleńskiego oraz $\mathrm{w}$ kręgach wojskowych związanych z wojewodą. I mimo że poeta za Kochanowskim zapewnia, że „sobie śpiewa a Muzom”26, to jednak w jego twórczości jest wiele bezpośrednich zwrotów do czytelnika; choć trudno wyłącznie na tej podstawie z pewnością stwierdzić, że te teksty były w jakiś sposób powielane, to wziąwszy jeszcze pod uwagę karierę Kunowskiego, można przypuszczać, że w przestrzeni publicznej zaistniały w obiegu rękopiśmiennym, a część z nich (w nieco zmienionym kształcie) była po prostu wygłaszana. Analiza utworów Kunowskiego spisanych już podczas dziesięciomiesięcznego oblężenia Smoleńska rozpoczętego pod koniec 1632 roku - Fragmenta oblężenia smoleńskiego... oraz $\mathrm{Na}$ angaryją oblężenia smoleńskiego uskarżanie - w kontekście tych ustaleń i hipotez prezentuje się wyjątkowo ciekawie.

Wspomniane wyżej dwa teksty, stanowiące w pewnym sensie całość, nie mają już charakteru panegirycznego; przeciwnie, są pełnym żalu zapisem przerażającego doświadczenia wojennego. Narracja opiera się w nich głównie na konkretnych wydarzeniach z czasu obrony Smoleńska, które jednakże przeplatane są uwagami o bardziej ogólnym charakterze, dotyczącymi między innymi spraw wojskowych, Rzeczypospolitej czy Moskwy, które decydują o ideologicznej wymowie tych poematów. Uwagę zwraca tu przede wszystkim - znacznie silniejsze niż w Zacności smoleńskiej... - zaakcentowanie wyrzutów względem organizacji odsieczy:

Azaż, Ojczyzno miła, zostaniesz bez winy

Potraciwszy cnotliwe bez ratunku syny?

W macochę się obrócisz z takowej przyczyny,

To widząc, umrzeć za cie już nie zachce iny.

25 K. Łopatecki, Wstęp, w: J. Kunowski, Ekspedycyja inflantska..., s. 30.

26 J. Kunowski, [Zacny pisorym polski nie darmo powiedział...], w: Sprawa smoleńska..., s. 76. 
Do szwagrów nie wołamy, bo-ć tych na zająca

Wezwać, ale o braciej nadziei do końca

Nie zejdzie prędko tracić. A wżdam sie obudzą,

Swej przygody uchodząc, poratują cudzą?

A ci śpią, pobłażając: ej, tam mężni siedzą,

Nieraz z tymi Moskali na tym Zamku biedzą.

A ówdzie czego pilnie, niedbalcy nie wiedzą,

Czym nas pewnie, niebożąt, już sami pojedzą.

Łatwie-ć to dokazować cudzym grzbietem męstwa,

A sam sie pilno trzymasz wnętrznego przestrzestwa ${ }^{27}$.

Lament Kunowskiego, pisany $\mathrm{w}$ tragicznych okolicznościach, zdecydowanie kontrastuje stylistycznie z pochwalną Zacnością smoleńska..., ale jednocześnie porusza miejscami te same problemy, takie jak na przykład uznawanie przez włodarzy Rzeczypospolitej Smoleńska za daleką prowincję i długie pozostawianie go bez militarnej i materialnej pomocy.

Dramatyczne położenie, w którym znaleźli się obrońcy, jeszcze mocniej wybrzmiewa w utworze Na angaryją oblężenia smoleńskiego uskarżanie - pierwszy jego wers to słowa: „Serce strapione, zewsząd pełne trwogi”28. Ten incipit to kolejna oznaka biegłości Kunowskiego w topice antycznej; strwożone w obliczu wizji rychłej klęski serce to obraz obecny zarówno w tradycji antycznej, jak i hebrajskiej - szczególnie ważne wydają się tu Eneida Wergiliusza (Aen. II,17-18) ${ }^{29}$ i bi-

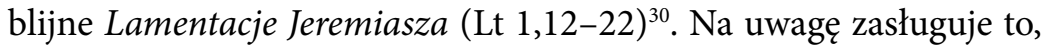
że obydwa te teksty, które przypuszczalnie mogły stanowić dla $\mathrm{Ku}$ nowskiego istotne odwołania, dotyczą rzeczywiście bardzo podobnych sytuacji, to jest tragicznego upadku miast - Troi i Jerozolimy.

27 J. Kunowski, Fragmenta oblężenia smoleńskiego Roku Pańskiego 1632 dnia 17 decembr<a> zaczętego, w: Sprawa smoleńska..., s. 70-71.

28 J. Kunowski, Na angaryją oblężenia..., s. 77.

29 Zob. np. Wergiliusz, Eneida, przeł. i oprac. Z. Kubiak, Warszawa 1987, s. 74.

30 Zob. np. Biblia Tysiąclecia. Pismo Święte Starego i Nowego Testamentu, Poznań - Warszawa 1971, s. 971. 
Wcześniej prezentowany idylliczny obraz Smoleńska ulega tu zupełnemu odwróceniu; zamiast spokojnych gajów są „niewybrnione lasy"31, zamiast znajomej szlachetnej zwierzyny pojawiają się mityczne potwory takie jak Scylla, Charybda i Polifem. Sielski obraz ptaków wzlatujących nad żyznymi gospodarstwami zostaje wyparty przez wizję ptaka umierającego w zaciskających się sidłach, a locus amoenus przeradza się stopniowo w locus horribilis.

Mimo tego przerażającego i ponurego wojennego imaginarium oraz nagromadzenia słów gorzkiej krytyki pod adresem państwa wątki propagandowe w tekstach Kunowskiego pisanych podczas samego oblężenia są wyraźnie widoczne. Na szczególną uwagę w tym kontekście zasługuje zwłaszcza demoniczna prezentacja wojsk nieprzyjaciela, komponująca się $\mathrm{z}$ obrazem cierpienia malowanym przez poetę. Należy zauważyć, że to najeźdźca czyni ukochaną przez autora Smoleńskiej zacności... krainę piekłem na ziemi i to on przynosi chaos i zło do uświęconej - zarówno przez Boże błogosławieństwo, jak i przez świecką narrację - przestrzeni.

Nieodmiennie we wszystkich tekstach Kunowskiego Smoleńsk jest miastem w pewien sposób wybranym przez Boga, ale wiara, jaką pokładają w Opatrzności obrońcy grodu, jest najwyraźniej obecna właśnie w lamentach:

W Zamek przez dzięki, nasi wejścia bronią,

Ratunku niskąd w tę nie widząc tonią,

Jedno od Ciebie, miłosierny Boże!

Twoja prawica tyle nas wspomoże,

Tobą się ciesząc, Tobą mężnie bronim,

Według Twej woli głowy nasze skłonim.

Drugie rycerstwo gdzieś w pokoju siedzi,

Nie chcąc tu najrzeć, jako nędznik biedzi

[...] O, jakiej macie spodziewać nagany!

Strzeż, Boże, Smoleńsk! [...]

Pospiesz sie, Boże, abyś nas ratował!

Pokwap się, Panie, abyś nas uchował

31 J. Kunowski, Na angaryją oblężenia..., s. 83. 


\section{[...] Zawaruj, Panie, gdyż w Tobie ufanie}

Pokłada nędznik, póki nie ustanie! $!^{32}$

Co szczególnie ciekawe, postawa podmiotu lirycznego odbiega od pełnych wątpliwości i wyrzutów czynionych Bogu słów Lamentacji Jeremiasza. Wydaje się, że dla Kunowskiego wiara - także wiara w słuszność własnych działań - pozostała najtrwalszą opoką.

\section{Zakończenie}

Omówione wyżej teksty pokazują, że organizacja przestrzeni mitu smoleńskiego opiera się na silnych opozycjach charakterystycznych dla retoryki propagandowej. Mowa tu już jednak nie tyle o przestrzeni mimetycznej, konstruowanej niemal na wzór kartograficzny, ile o przestrzeni symbolicznej, w której kształtuje się sama opowieść o wojnie. Najbardziej oczywista ze wspomnianych opozycji, widoczna w utworach Kunowskiego o tematyce wojennej, to ta między walczącymi armiami, ale pociąga ona za sobą szereg dychotomii przynależnych do różnych porządków, między innymi religijnego, politycznego czy kulturowego. Stojące po jasnej stronie cywilizacji chrześcijańskiej wojska Rzeczypospolitej zestawione zostały z ciemnymi, dzikimi i wręcz "gorszymi niż pogańskie" 33 siłami moskiewskimi, co pozwala na odniesienie historii wojny smoleńskiej do rozmaitych, tradycyjnych dla myśli europejskiej koncepcji, takich jak chociażby idea wojny sprawiedliwej czy męczeństwa.

W kształtowaniu przestrzeni mitycznej Kunowski posługiwał się jednak nie tylko motywami chrześcijańskimi - dość swobodnie korzystał także z topiki starożytnej; w konwencjonalny dla sobie współczesnych twórców sposób konceptualizował wojnę, odwołując się

32 Ibidem, s. 78-79.

33 Ibidem, s. 79. 
chociażby do alegorii wywodzących się z grecko-rzymskiego panteonu. Szczególnie ciekawie wyglądają odniesienia do mitu trojańskiego, ponieważ poeta widzi wojska polsko-litewskie raz jako Trojan („Jak długo Troja tam najazdy greckie / Cierpiała, tak my znosim tu niemieckie”), a raz jako Greków („Jako w trojańskim niegdy koniu była / Męźów moc dzielnych, tak w Smoleńsku siła / Gosiewski zawar1"35). Jasne wydaje się, że nie chodziło o głębokie i kunsztowne porównanie wartościujące którekolwiek z wojsk według określonej interpretacji mitu trojańskiego, ale o dramatyzację wojny smoleńskiej i włączenie jej do europejskiej mitologii.

Podsumowując niniejsze rozważania, chciałbym zauważyć, że istnieją dwa główne klucze analizy mitu smoleńskiego. Pierwszy to ten odnoszący się do bieżących wydarzeń politycznych (wojny, aneksji, kapitulacji itd.), drugi zaś - metanarracyjny, ujmujący opowieść $\mathrm{w}$ szersze ramy tożsamościowe i związany z różnie pojmowaną identyfikacją kulturową. Treści propagandowe dotyczą w pierwszym aspekcie przeważnie rzeczywistych jednostek, czyli konkretnych faktów i osób, a w drugim - mniej uchwytnych wielkich idei społecznych. Oczywiście trudno te kategorie zupełnie rozdzielać; znaczenia z obydwu kręgów przenikają się nieraz nawet w obrębie poszczególnych mitemów (obrazów, symboli, sformułowań właściwych dla tej opowieści), ale skala oddziaływania każdej z nich musi być analizowana $\mathrm{z}$ uwzględnieniem wspomnianych poziomów.

Dokonana przeze mnie analiza utworów Jana Kunowskiego dotyczących Smoleńska pozwala zauważyć, że istnieją pewne - dość silnie skonwencjonalizowane - punkty węzłowe mitu smoleńskiego. Pełnią one rozmaite funkcje: mogą na przykład legitymizować władzę królewską, sankcjonować prawa Rzeczpospolitej Obojga Narodów do ziemi smoleńskiej czy podnosić morale wojska i ludności cywilnej. Takie studium przypadku, odnoszące się do konkretnego

34 Ibidem, s. 83. Chodzi tu o najemne (m.in. niemieckie) wojska w służbie carskiej.

35 J. Kunowski, Do czytelnika, w: Sprawa smoleńska..., s. 84. 
wydarzenia historycznego, pozwala także na wyciągnięcie bardziej ogólnych wniosków na temat centralnych procesów, które miały decydujący wpływ na tworzenie metanarracji kształtujących nowożytne społeczeństwo Rzeczypospolitej.

\section{Bibliografia}

Augustyniak U., Informacja i propaganda w Polsce za Zygmunta III, Warszawa 1981. Awianowicz B., „Urbes laudandi ratio”. Antyczna teoria pochwaly miast i jej recepcja $w$ De inventione et amplificatione oratoria Gerarda Buccoldianusa oraz $w$ Essercitii di Aftonio Sofista Orazia Toscanelli, „Terminus” 11 (2009), z. 1-2, s. 15-31.

Biblia Tysiąclecia. Pismo Święte Starego i Nowego Testamentu, Poznań - Warszawa 1971.

Buszewiczowa E., Cracovia in litteris. Obraz Krakowa w piśmiennictwie doby odrodzenia, Kraków 1998.

Chemperek D., Obraz Smoleńska i jego mieszkańców w literaturze polskiej początku XVII wieku, „Terminus” 11 (2009), z. 1-2, s. 217-228.

Chrościcki J., Sztuka i polityka. Funkcje propagandowe sztuki w epoce Wazów 1587-1668, Warszawa 1983.

Curtius E.R., Literatura europejska i łacińskie średniowiecze, przeł. i oprac. A. Borowski, Kraków 2005.

Fish S., Retoryka, w: idem, Interpretacja, retoryka, polityka, przeł. K. Arbiszewski i in., red. A. Szahaj, Kraków 2002, s. 421-462.

Kunowski J., Sprawa smoleńska. Z literatury okolicznościowej pierwszej połowy XVII wieku. Ze zbiorów Archiwum Narodowego Szwecji Skoklostersamlingen, wyd. M.M. Kacprzak, red. A. Nowicka-Jeżowa, Warszawa 2006.

Kunowski J., Ekspedycyja inflantska 1621 roku, oprac. K. Łopatecki, W. Walczak, Białystok 2007.

Kupisz D., Smoleńsk 1632-1634, Warszawa 2001.

Limbereger M., A Merchant Describing the City. Lodovico Guicciardini's „Descrittione di tutti I Paesi Bassi" as a Source for the Urban History of the Low Countries, https://biblio.ugent.be/publication/936765/file/950595.pdf (dostęp: 9 I 2017).

Niemcewicz J.U., Spiewy historyczne, oprac. M. Hanczakowski, Kraków 2002.

Wergiliusz, Eneida, przeł. i oprac. Z. Kubiak, Warszawa 1987. 